\title{
The example of the UK SHOT haemovigilance system
}

\author{
Perla Eleftheriou
}

\author{
St Bartholomew's Hospital, London, UK
}

\begin{abstract}
SHOT (Serious Hazards of Transfusion scheme) is the UK's National confidential haemovigilance system, and was set up in 1996. It is an independent, confidential, professionally led haemovigilance scheme. Initially the reporting was voluntary but now required by several professional bodies. SHOT publishes annual reports with recommendations and circulates to all relevant organizations including the 4 UK Blood services, Departments of Health in England, Wales, Scotland and Northern Ireland, all relevant professional bodies and reporting hospitals. Over the 17 years of reporting, the evidence gathered has prompted changes in transfusion practice from the selection and management of donors to changes in hospital practice, better education and training. Acute transfusion reactions and transfusion-associated circulatory overload carry the highest risk for morbidity and death. Greatest risk to patients remain errors in the process at the point of blood sampling, in the laboratory and at bedside administration. SHOT's objectives are to use findings to improve standards of hospital transfusion practice, to educate users on transfusion hazards and prevention, to aid production of clinical guidelines in blood transfusion and to inform national policy on transfusion safety. MHRA is the UK competent authority to which serious adverse reactions and events have to be reported annually. Overall the most common adverse incidents are caused by errors, resulting in the transfusion of an incorrect component or one that does not meet the specific requirements of the patient (e.g. not irradiated or not appropriately antigen matched). TACO (transfusion associated circulatory overload) accounts for most deaths and major morbidity reported to SHOT but is overall underreported. Transfusions are not always given appropriately. This may be
\end{abstract}

due to wrong haemoglobin results, failure to assess patients appropriately, or avoidable use of emergency $0 \mathrm{RhD}$ negative units because of poor communication or planning. Review of cases of haemolytic transfusion reactions (HTR) shows that they are observed mainly in Sickle Cell Disease patients. HTR are associated with major morbidity (10/16 cases in sickle cell patients over 3 years) and death (a child in 2010). SCD patients are at particular risk of alloimmunization and this can be reduced by red cell phenotyping prior to the first transfusion followed by routine matching for at least the Rh and Kell groups. SHOT output data led over the time to the development of strategies to improve transfusion safety such as the implementation of guidelines for improving practice, implementation of the National Comparative Audit of Blood Transfusion programme, the publication of the Better blood transfusion initiatives and the establishment of The UK transfusion laboratory collaborative.

\section{Key learning points from SHOT}

1. Transfusion is very safe in the UK with very low risk of bacterial or viral infection

2. Correct patient identification and adherence to basic procedures are key to safer practice

3. Errors continue to make up $>50 \%$ of all events reported to SHOT

4. Acute transfusion reactions are the now the leading cause of major morbidity

5. TACO is a serious complication (43\% of reported cases resulted in death or major morbidity in 2012)

6. Adverse events reporting and investigation has resulted in changes in transfusion practice which have reduced pathological reactions (i.e. bacterial infections and TRALI).
Correspondence: Perla Eleftheriou, St Bartholomew's Hospital, London, UK E-mail: perla.eleftheriou2@bartshealth.nhs.uk

Key words: UK SHOT; haemovigilance system; haemolytic transfusion reactions; haemoglobin.

(C) Copyright P. Eleftheriou, 2014

Licensee PAGEPress, Italy

Thalassemia Reports 2014; 4:4858

doi:10.4081/thal.2014.4858

This article is distributed under the terms of the Creative Commons Attribution Noncommercial License (by-nc 3.0) which permits any noncommercial use, distribution, and reproduction in any medium, provided the original author(s) and source are credited. 